\title{
When science and theology meet
}

Religion is religion, science is science, and good fences make good neighbours. That seems likely to be the thrust of an expected clarification by the Roman Catholic Church of its position on biological evolution, according to a prominent biologist who spoke at a retreat on the topic held last weekend by Pope Benedict XVI.

This outcome would be a blow to supporters of intelligent design who had hoped that factions in the Vatican sympathetic to their ideas might prevail in an internal feud over evolution that has opened since the death of Pope John Paul II in April last year. That could have given a global axis to what has been largely a US cultural phenomenon.

John Paul II perhaps did more than any pontiff to reconcile faith and science, declaring in 1980 that there was no contradiction between the two. He subsequently described darwinian evolution as more than a hypothesis, and in 1992 officially rehabilitated Galileo Galilei, admitting the Church's fault. Benedict XVI, however, has long been more ambiguous on the topic. In his first mass as Pope, he stated that "we are not some casual and meaningless product of evolution".
Last year, the prominent Cardinal Christoph Schönborn wrote an article in The New York Times expressing doubts about darwinism. He also seemed to advocate intelligent design, a movement whose advocates seek to give creationism scientific credibility by arguing that the complexity of science can be explained only by divine intervention in the process of evolution.

Although Schönborn has since backpedalled on the way his ideas were expressed in the article, the piece fuelled rumours that Rome, which currently endorses darwinian evolution and rejects any literal interpretation

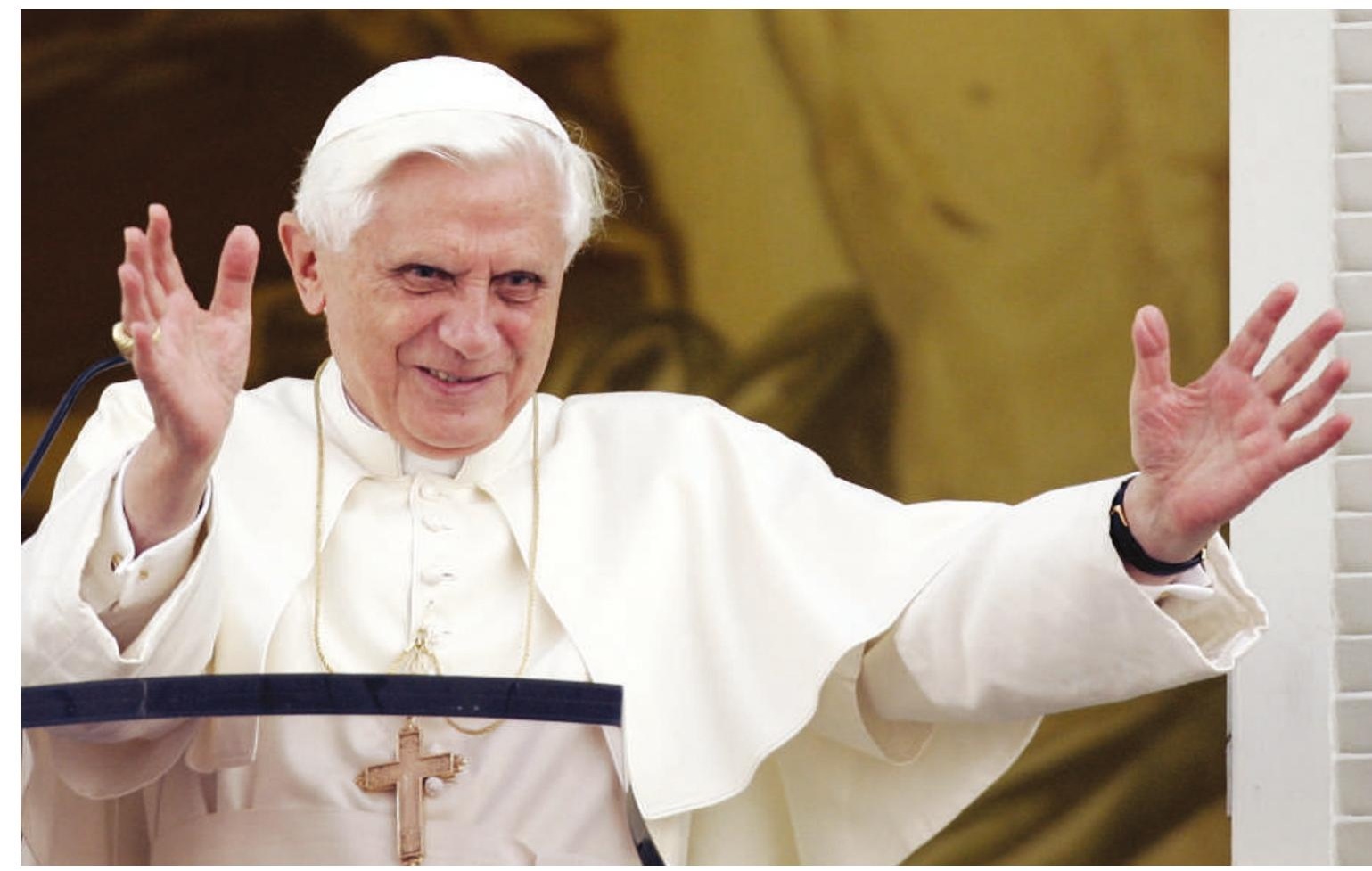

Creative thought: Pope Benedict XVI is wrestling with how to square evolution with religion.

\section{French confusion leaves Iranians locked out of meeting}

\section{PARIS}

Global politics has soured the runup to this week's TNT2006 Trends in Nanotechnology conference in France. Organizers initially banned some 15 Iranian researchers from attending, citing political concerns over Iran's nuclear programme.

The decision has since been revoked and two Iranians will now attend the conference on 4-8 September in Grenoble. The remainder have withdrawn, according to the organizers, because of problems such as visa delays. But the incident has raised concerns that the current political situation, in which Iran faces international isolation over its refusal to stop its uranium enrichment programme, may cause scientists from the country to be ostracized.

Those involved in the conference have denied any discrimination against Iranian scientists, and say the incident is the result of a series of misunderstandings about the security-clearance rules. The congress centre in which the conference is being held is inside Minatec, a sprawling research and industrial complex that belongs to the French Atomic Energy

Commission (CEA).

When Antonio Correia, president of conference organizers the PHANTOMS Foundation in Madrid, began receiving submissions from Iran he contacted Didier Molko, CEA director of Minatec, to check whether this raised any security concerns. Molko told him that "CEA rules say that Iranian people can't go in". As a result, Correia e-mailed the Iranian applicants on 9 June, apologizing that "we must withdraw your contribution and participation", a move he says met an angry response. "I understand that people were angry," says Correia. "Science should have nothing to do with politics."

Molko now says his initial decision was a personal mistake, and not CEA policy. He was being cautious because of the political situation, he says, but after checking with his superiors in Paris, he revoked his earlier decision. "It was a delay of a week or two at most."

Pascal Newton, a spokesman for CEA headquarters in Paris, says that the commission's security services check out all visitors to CEA buildings on a case-by-case 
of biblical creation, might instead endorse intelligent design.

Speculation increased last month when Schönborn announced that creation and evolution would be the topic of the Pope's annual retreat, to be held in Castel Gandolfo near Rome. As a former cardinal and German theology professor, Joseph Ratzinger has long held this informal gathering, where he discusses a hot topic with his past students. But the retreat has taken on new significance since Ratzinger became Pope.

Bruce Chapman, president of the Discovery Institute in Seattle, Washington, which represents the intelligent-
"I got the impression that there was general agreement that evolutionary biology is a undeniable science and not a hypothesis." however, the precise outcome of the overall debate is impossible to predict, he says: "We have to wait."

But discussions at the meeting suggest that the Church will probably affirm a form of theistic evolution, which posits the general principle that biological evolution is valid, although set in motion by God. At the same time, it seems likely to reject the fundamental intelligentdesign principle that God was a watchmaker, intervening in the details. "Intelligent design as an intervention of God during evolution will not be an outcome," predicts Schuster. "I got the impression that there was general agreement that design movement, welcomed the choice of topic in a press release published on the institute's website last week. In it he wrote: "What's good about all this is that they're taking up the issue seriously... it will be conducted at a very high level and I think it should give cheer to people who are critics of Darwinism."

Schönborn was one of four invited speakers at the meeting, which also included Robert Spaemann, a conservative German philosopher, and Paul Erbrich, a Jesuit priest who questions the random nature of evolution. The fourth speaker, the only working scientist present, was Peter Schuster, a molecular biologist and president of the Austrian Academy of Sciences.

In a break with tradition, the proceedings of the meeting will be published later this year, says Schuster, with a preface written by the Pope. The message will be to promote dialogue between faith and reason, Schuster says. Given the power struggles within the Church, evolutionary biology is a undeniable science and not a hypothesis."

The Pope in particular "immediately accepted that theology is not going to interfere with science", Schuster adds. "He is not a scientist, but I was surprised by the sharpness of his intellect. He wanted to be informed; he was very interested in science."

But although there is likely to be agreement that the Church should not attempt to question the basic theory of evolution, those at the meeting were also adamant that science should not stray into theology. Schuster says there was a wide desire to address the Church's concern that darwinism is being extrapolated as a wider metaphysical stance. This argues that we are random products of evolution, and that there is therefore no need for God. "I agree that, as in science, everyone should stay within their realms of competence," says Schuster.

Declan Butler basis. "We get a simple, yes/no; we never know why." Particular nationalities aren't officially banned, he says, although he adds: "In the current political context, I can imagine Iran might be more sensitive."

The United

Nations Security

Council set a

deadline of last

week for Iran to

suspend uranium

enrichment

activities, which it

suspects are part of a

programme to develop nuclear

weapons. Iran ignored the

deadline and, failing last-ditch negotiations this week, the council is set to impose economic sanctions on the country.

International isolation in similar situations has in the past spared scientific cooperation. "In the long term, Indeed, during the the best scientists cold war, contact will continue to collaborate with Iranian scientists. between scientists was one of the few channels open between East and West. But Reza

Mansouri, a well-known Iranian physicist based at the Sharif University of Technology in Tehran, complains that his country's scientists are already falling victim to discrimination, such as visa delays. He also worries about what he sees as widespread ostracization by fellow scientists, and he deplores the incident in France.

But Mansouri says he believes it is a temporary problem induced by the tense international climate. "In the long term, the best scientists will continue to collaborate with our scientists, bringing more rationality and understanding into the dialogue, and ultimately more peaceful attitudes."

Declan Butler
ON THE RECORD

(CThey are wanted to be kissed. This is the reason why the two young ladies are invited.")

Igor Tkatchenko, vice-chairman of the French Chemical Society, bringing on stage two women chemists who got honourable mentions at the European Young Chemist Awards in Budapest.

\section{( $\mid$ could argue the} case with hand puppets and win.")

Attorney David Bookbinder on the argument that the US Environmental Protection Agency should restrict emissions of greenhouse gases.

\section{“CETs....could also be creatures of God.»}

Father Jose Funes, new director of the Vatican Observatory, ponders the nature of intelligent life elsewhere in the Universe.

\section{NUMBER CRUNCH}

$15 \%$ of HIV-positive people in the world live in India.

$0.9 \%$ of Indian adults have HIV.

$64 \%$ of Indian lawmakers believe $\mathrm{HIV}$ can be passed on by sharing clothes with an infected person.

\section{SCORECARD}

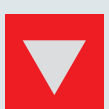
Iraq archaeology He stayed longer than many Iraqi academics, but Donny George, the country's most prominent archaeologist, has finally given up. George was known for his efforts to recover antiquities looted after the war in 2003. But he has now resigned and fled to Syria, citing security problems and lack of funding.

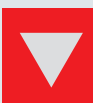

Blue skies research Scientists in Britain will need to fight a little harder to justify their funding. UK research councils will now include wealth creation experts on all funding panels, to help judge which projects deserve to receive the money.

Sources: San Francisco Chronicle, Indian Catholic, Indian Association of Parliamentarians, UNAIDS 